\title{
ljtihad Ekonomi dalam Pengelolaan Aset Wakaf
}

\author{
Amir Mu'allim
}

\begin{abstract}
Economic Ijtihad In The Waqf Assets Management. In Islamic legal system, every case that is not explicitly stated in its legal provisions by the Qur'an and Hadith automatically enters the realm of legal interpretation (ijtihad). This applies also to waqf (endowment fund) cases. Considering that waqf implementation is not explained in detail in the Qur'an and Hadith, its implementation, then, becomes free-for- all flexible and dynamic interpretation. This research examines the practices of waqf under the Indonesian Islamic University Foundation (UII) and the Sultan Agung Waqf Board Foundation (YBSA), Semarang. The study focuses on the model of economic ijtihad implemented by the two bodies in developing and managing waqf assests. This study finds out that YBSA turned all assets of the foundation into waqf assets regardless all of the existing assets were combination between capital and the result of the development (started in the form of elementary schools then developed to colleges and hospitals). In the study of Islamic law, combining capital with the results of development as practiced by YBSA is a novelty in the management of waqf and can be termed economic ijtihad.
\end{abstract}

Keywords: economic ijtihad, waqf development, Yayasan Badan Wakaf Sultan Agung

\begin{abstract}
Abstrak: Ijtihad Ekonomi dalam Pengelolaan Aset Wakaf. Di dalam Fikih Islam, setiap kasus yang tidak secara tegas disebutkan ketentuan hukumnya oleh dalil secara otomatis masuk ke dalam ranah penafsiran hukum (ijtihad). Hal ini berlaku juga untuk kasus wakaf. Mengingat pelaksanaannya tidak secara detail dijelaskan dalam Aquran dan Hadits maka hal tersebut menjadi sangat terbuka bagi penafsiran yang fleksibel dan dinamis. Studi ini menelaah tentang praktik wakaf pada Yayasan Badan Wakaf Universitas Islam Indonesia (UII) dan Yayasan Badan Wakaf Sultan Agung (YBSA), Semarang. Fokus persoalan pada penelitian ini adalah model ijtihad ekonomi yang dijadikan landasan dalam pengelolaan dan pengembangan wakaf. Penelitian ini menemukan bahwa fakta bahwa YBSA menjadikan seluruh aset yayasan sebagai aset wakaf meskipun sebenarnya seluruh aset yang ada merupakan hasil pengembangan dari modal wakaf (pada awalnya berupa sekolah-sekolah dasar kemudian berkembang hingga memiliki perguruan tinggi dan Rumah Sakit). Dalam kajian hukum Islam, menggabungkan modal dengan hasil pengembangan sebagaimana yang dilakukan oleh YBSA merupakan ijtihad baru dalam pengelolaan wakaf dan diistilahkan dengan ijtihad ekonomi.
\end{abstract}

Kata Kunci: ijtihad ekonomi, pengembangan wakaf, Yayasan Badan Wakaf Sultan Agung

Guru Besar Hukum Islam Fakultas Ilmu Agama Islam Universitas Islam Indonesia

Jl. Kaliurang KM 14.5, Umbulmartani, Sleman, Daerah Istimewa Yogyakarta 55581

E-mail: amirmuallim@yahoo.com 


\section{Pendahuluan}

Islam mengajarkan adanya keseimbangan sosial ekonomi, dalam ekonomi dikenal dengan konsep distribusi kekayaan. Konsep ini bekerja sebagai upaya agar harta tidak hanya berputar di kalangan orang-orang kaya saja, tetapi ada pemerataan dengan mendistribusikan kekayaan kepada orang-orang yang berkekurangan, sehingga tidak hanya sekedar kewajiban sosial belaka tetapi juga sebagai bentuk keimanan dan tali persaudaraan dalam bingkai Islam. Islam mengajarkan kepada umat Islam model-model instrumen ekonomi Islam untuk menjamin keadilan sosial dan pemerataan ekonomi, yaitu kewajiban zakat, infak, dan wakaf. ${ }^{1}$

Berkaitan dengan ajaran wakaf, Islam menjadikannya sebagai instrumen yang lebih ekspansif yang mengajak para pengelolanya lebih

${ }^{1}$ Terkait zakat, infak, dan wakaf bisa dilihat dalam beberapa karya tulis di antaranya Sheila $\mathrm{Nu} \mathrm{Nu}$ Htay, Syed Ahmed Salman, Soe Myint, and Haji Ilyas. "Integrating Zakat, Waqf and Sadaqah: Myint Myat Phu Zin Clinic Model in Myanmar." Tazkia Islamic Finance and Business Review 8, no. 2 (2014). A. R. Khairuddin, H. Sharina Farihah, A. S. Azila, O. Jamilah, and A. Srazali. "Preliminary Discussion on the Potential of Zakat-Waqf Collaboration in the Provision of Housing for The Needy Muslims." In Proceedings of the National Conference on Zakat and Economic Development. 2015. M. Kabir Hassan. "An Integrated Poverty Alleviation Model Combining Zakat, Awqaf And Micro-Finance." In Seventh International Conference-The Tawhidic Epistemology: Zakat and Waqf Economy, Bangi, Malaysia, pp. 261-281. 2010. Lukman Raimi, Ashok Patel, and Ismail Adelopo. "Corporate Social Responsibility, Waqf System And Zakat System As Faith-Based Model For Poverty Reduction." World Journal of Entrepreneurship, Management and Sustainable Development10, no. 3 (2014): h. 228-242. Asep Saepudin Jahar. "The Clash Of Muslims And The State: Waqf And Zakat In Post Independence Indonesia." Studia Islamika 13, no. 3 (2006). Hidayatul Ihsan, and Shahul Hameed Hj. Mohamed Ibrahim. "WAQF Accounting And Management In Indonesian WAQF Institutions: The Cases Of Two WAQF Foundations." Humanomics 27, no. 4 (2011): h. 252-269. Shinsuke Nagaoka. "Resuscitation of the Antique Economic System or Novel Sustainable System?: Revitalization of the Traditional Islamic Economic Institutions (Waqf and Zakat) in the Postmodern Era (Special Feature: SocioEconomic Role of Islamic Finance and its Potential in the Post-Capitalist Era).” イスラーム世 界研究 7 (2014): h. 3-19. Abdul Rahman, Abdul Rahim. "Islamic Microfinance: An Ethical Alternative to Poverty Alleviation." Humanomics 26, no. 4 (2010): h. 284-295. Azliza Azra Mohd Zakaria, Rose Ruziana Abd Samad, and Zurina Shafii. "Venture Philanthropy Waqf Model: A Conceptual Study." Jurnal Pengurusan (UKM Journal of Management) 38 (2013). Muhammad Anas Zarka. "Leveraging Philanthropy: Monetary Waqf For Microfinance." In Sharia Compliant Microfinance, pp. 90-94. Routledge, 2013. Nasim Shah Shirazi. "Integrating Zakât and Waqf Into the Poverty Reduction Strategy of the IDB Member Countries." (2014). Dahlia Ibrahim, and Hasnidar Ibrahim. "The Revitalization of Islamic Trust Institution Through Corporate Waqf." In 4th International Conference on Business and Economic Research Proceedings. 2013. Ahmad Affandi, and Diah Nurhayati Nufus. "Analysis On Cash Waqf Return Fund Allocation In Indonesia: Acase Study In Indonesian Waqf Deposit." In Seventh International Conference-The Tawhidi Epistemology: Zakat and Waqf Economy, pp. 119-135. 2010. 
berjiwa entrepreneur. Harta wakaf hanya sebagai modal sementara hasilnyalah yang pokok derma untuk pengembangan ekonomi umat. ${ }^{2}$

Pemanfaatan harta wakaf bukan untuk tujuan konsumtif yang menghabiskan pokok atau substansi aktivanya. Pemanfaatan secara berkesinambungan bagi tujuan tujuan kebajikan mengandung arti bahwa hasil atau buah dari harta wakaf itulah yang dikehendaki. Meskipun, tidak menutup kemungkinan adanya syarat-syarat khusus yang ditetapkan oleh wakif, seperti wakif turut memanfaatkan harta wakaf itu, sebagaimana yang dibolehkan oleh sebagian mazhab. ${ }^{3}$

Wakaf merupakan doktrin yang amat penting guna membangkitkan peradaban Islam. Pada masa kejayaan Islam, wakaf telah memainkan peran penting dalam kemajuan masyarakat muslim. Pada masa lalu, pusat-pusat peradaban, kebudayaan, dan keilmuan banyak yang disokong oleh aset-aset wakaf. Pendanaan riset dan fasilitas beasiswa juga dibiayai dari perberdayaan wakaf. Universitas al-Azhar Kairo, misalnya, sejak berdiri pada abad ke-10M hingga sekarang masih memanfaatkan aset wakafnya untuk biaya operasional. Tanah-tanah wakafnya yang strategis dipergunakan untuk toko dan hotel guna membiayai program universitas. ${ }^{4}$

Perwakafan di Indonesia bukanlah suatu yang baru, bahkan jumlah tanah wakaf di Indonesia mencapai 435.768 dengan total luas 4.359.443.170 m2, ${ }^{5}$ luas tanah ini merupakan wakaf yang sangat besar. Namun demikian, pemberdayaan wakaf secara produktif di Indonesia masih sangat minim, padahal banyak tanah wakaf di Indonesia yang bernilai ekonomi tinggi. Beberapa lembaga pendidikan berbasis wakaf menjadi contoh riil keberhasilan pengelolaan harta wakaf, misalkan Yayasan Badan Wakaf Pondok Modern Darussalam Gontor, Ponorogo, Jawa Timur, Yayasan Badan wakaf Sultan Agung (YBSA), Yayasan Badan Wakaf Universitas Islam Indonesia (YBW UII), Yayasan Wakaf

${ }^{2}$ HM. Cholil Nafis. "Reaktualisasi Ajaran Wakaf," t.t., http://bwi.or.id/index.php/en/ publikasi/artikel/637-reaktualisasi-ajaran-wakaf.html.

${ }^{3}$ Ahmad Djalaludin. "Legitimasi Fiqih Bagi Obtimalisasi dan Pendayagunaan Wakaf", Iqtishoduna: Jurnal Ekonomi dan Bisnis Islam 3, no. 1, (2007), h. 4.

${ }^{4}$ Tri Wahyu Hidayati, Problematika Pengelolaan Wakaf di Indonesia, t.t.

${ }^{5}$ Lihat "Data Direktorat Pemberdayaan Wakaf Kementerian Agama RI," Maret 2016, 1. 
Paramadina, dan Badan Wakaf Universitas Muslimin Indonesia (UMI) di Makasar. ${ }^{6}$

Namun demikian, Perwakafan di Indonesia secara umum masiih jauh tertinggal dibanding negara lain, seperti Mesir, Aljazair, Arab Saudi, Kuwait, dan Turki. Negara-negara tersebut telah sukses mengelola wakaf lebih produktif dalam semua bidang kepentingan publik. Bahkan, di negara yang penduduk muslimnya minoritas, Singapura, aset wakafnya per Desember 2013 memiliki lebih dari 100 aset properti. Sebagian besar dikelola Majlis Ugama Islam Singapura (MUIS) sendiri, sebagian lainnya oleh wali amanat, aset ratusan properti tersebut senilai Rp 7,5 triliun. ${ }^{7}$

Pokok masalah yang menjadi fokus dalam tulisan ini adalah ijtihad ekonomi dalam pengelolaan dan pengembangan wakaf di Yayasan Badan Wakaf Sultan Agung, Semarang dan Yayasan Badan Wakaf Universitas Islam Indonesia, Yogyakarta. Tujuan utama dari kajian wakaf di dua yayasan wakaf tersebut adalah untuk mendapat penjelasan model pengelolaan dan pengembangan wakaf untuk kepentingan pengembangan pendidikan Islam, sehingga akan menjadi model ijtihad dalam pengelolaan wakaf di Indonesia.

\section{Dasar Normatif Perwakafan}

Ajaran Wakaf dalam Alquran tidak secara jelas dan tegas disebutkan, ada ayat-ayat yang digunakan sebagai dasar hukum perintah wakaf, yaitu; "Hai orang-orang yang beriman, nafkahkanlah (di jalan allah) sebagian dari hasil usahamu yang baik-baik dan sebagian dari apa yang Kami keluarkan dari bumi untuk kamu. Dan janganlah kamu memilih yang buruk-buruk lalu kamu menafkahkan daripadanya, padahal kamu sendiri tidak mau mengambilnya melainkan dengan memincingkan mata terhadapnya. Dan ketahuilah, bahwa Allah Maha Kaya lagi Maha Terpuji's selain itu

${ }^{6}$ Tri Wahyu Hidayati, Problematika Pengelolaan Wakaf di Indonesia, h. 15.

7 Nur Kholis, Wakaf dan Upaya Pemberdayaan Potensinya Secara Produktif di Indonesia, dalam Pribumisasi Hukum Islam (Yogyakarta: PPs-FIAI UII, 2012), 149. Lihat juga informasi kompas yang dikutip "Aset Wakaf Property MUI Singapura Senilai Rp 7,5 T," t.t., http://www. beritawakaf.com.

${ }^{8}$ Al-Baqarah ayat 267. 
ada perintah perbuatan kebajikan. Allah berfirman: "Hai orang-orang yang beriman, rukulah kamu, sujudlah kamu, sembahlah Tuhanmu dan perbuatlah kebajikan, supaya kamu mendapat kemenangan".

Kata khair yang secara umum memiliki arti salah satunya dalam bentuk memberi wakaf, dan juga untuk bentuk sejenis seperti charity atau endowment yang lain yang bersifat filantropi, tentunya dalam ajaran Islam.

Hukum berwakaf adalah sunnah muakkadah (sangat dianjurkan) karena wakaf merupakan shadaqah jariyah yang pahalanya terus mengalir, meskipun wakif telah meninggal dunia. Hal ini didasarkan pada Alquran: "Kamu sekali-kali tidak sampai kepada kebajikan (yang sempurna), sebelum kamu menafkahkan sehahagian harta yang kamu cintai. Dan apa saja yang kamu nafkahkan maka sesungguhnya Allah mengetahuinya." 10

Berbeda dengan kata khair, kata birr terkait erat dengan kata infaq. Kata birr ini terletak antara huruf lan (mengandung makna tidak untuk selamanya) dan hattâ (hingga atau sampai yang berhubungan dengan tindakan). Sehingga ada 3 kata kunci pada ayat ini sehingga sering kali dijadikan dalil utama dalam wakaf yang bersumber dari Alquran, (1) kebaikan, (2) tindakan infak, dan (3) harta yang dimiliki adalah paling dicintai. Psikoanalisis mengatakan tidak mungkin orang memberikan harta yang paling dicintai kepada orang lain demi kebaikan. Salah satu analisis itulah sehingga kebaikan dalam konteks kata birr sulit untuk dilakukan. Oleh para penafsir model infak seperti ini, digolongkan sebagai wakaf, bukan bentuk pemberian yang lain. Surat Ali-Imran ayat 92 ini berisi anjuran bagi umat muslim untuk berinfaq/shadaqah. Imam Ahmad meriwayatkan dengan isnadnya dari Abû Ishaq bin Abdullah bin Abi Thalhah. Dia mendengar Anas bin Malik berkata, "Abû Thalhah adalah orang Anshar yang paling banyak hartanya, dan yang paling dicintainya adalah kebun Bairuha." Maka ketika turun ayat ini, Abû Thalhah segera menyedekahkan kebun Bairuha' yang dimilikinya tersebut. ${ }^{11}$

Salah satu hadis yang memberikan makna shadaqah jariyah adalah

${ }^{9}$ Al-Hajj, ayat 77.

${ }^{10}$ Âli 'Imrân, ayat 92.

${ }^{11}$ Ali Amin Isfandiar, "Tinjauan Fiqh Muamalat dan Hukum Nasional tentang Wakaf di Indonesia," Jurnal Ekonomi Islam 2, no. 1 (t.t.), h. 55. 
wakaf sebagaimana hadits dari Abû Hurairah r.a.,: "Jika seseorang meninggal dunia, maka terputuslah amalannya kecuali tiga perkara (yaitu): sedekah jariyah, ilmu yang dimanfaatkan, atau do'a anak yang shalih" (H.r. Muslim). ${ }^{12}$

Dimaksud sedekah jariyah adalah amalan yang terus bersambung manfaatnya. Seperti wakaf aktiva tetap (contoh: tanah), kitab, dan mushaf Alquran. Inilah alasannya kenapa Ibnu Hajar Al-Asqalani memasukkan hadis ini dalam bahasan wakaf dalam Bulûghul Maram. Karena para ulama menafsirkan sedekah jariyah dengan wakaf.

Syaikh 'Abdullah Al-Fauzan berkata, "Hadis ini jadi dalil akan sahnya wakaf dan pahalanya yang besar di sisi Allah. Di mana wakaf tersebut tetap manfaatnya dan langgeng pahalanya. Contoh, wakaf aktiva tanah seperti tanah, kitab, dan mushaf yang terus bisa dimanfaatkan. Selama benda-benda tadi ada, lalu dimanfaatkan, maka akan terus mengalir pahalanya pada seorang hamba. ${ }^{13}$

Juga dalam hadis dari Qutaibah ibn Sa'ad dari Muhammad ibn Abdullah al-Anshari dari Ibnu 'Aun dari Nafi' dari Ibnu Umar ra, yang diriwayatkan dalam Shahih Bukhari menyatakan bahwa:

"Umar mendapat sebidang tanah di Khaibar, kemudian ia menghadap Nabi Saw. untuk minta petunjuk tentang pengelolaannya, seraya berkata: 'Wahai Rasulullah Saw., saya mendapat sebidang tanah di Khaibar. Belum pernah saya memperoleh harta yang lebih bagus daripada ini.' Apa saran anda sehubungan dengan hal itu? Beliau bersabda: 'jika kamu suka, kamu tahan tanah itu dan kamu sedekahkan manfaatnya.' Maka Umar mnyedekahkan hasil tanah itu dengan syarat tanahnya tidak boleh dijual, dibeli, diwariskan atau dihibahkan. Umar menyedekahkan hasilnya kepada fakir miskin, kerabat, untuk memerdekakan budak, jihad fi sabilillah, untuk bekal orang yang sedang dalam perjalanan dan hidangan tamu. Orang yang mengurusnya boleh makan sebagian hasilnya dengan cara yang baik dan boleh memberi makan temannya secara ala kadarnya". ${ }^{14}$

${ }^{12}$ Lihat Kitab Shahih Muslim no. 1631.

${ }^{13}$ Abdullah bin Shalih Al-Fauzan, Minhah Al-Allam fi Syarh Bulugh Al-Marram Cet. ketiga (Dar Ibnul Jauzi, 2011), 7: 11.

${ }^{14}$ Muhammad Ibn al-Bukhari, Shahih al-Bukhari, 1981, dalam Kitab asy-Syurut fi al Waqfi (Bayrut: Dar al-Fikri, t.t.), h. 185. 
Sedangkan pendapat ulama yang menjadi dasar hukum wakaf uang adalah fatwa Imam al-Zuhri yang menganjurkan wakaf dinar dan dirham umtuk pembangunan sarana dakwah, sosial dan pendidikan umat Islam. Ada juga pendapat ulama mazhab al-Syaf'i: "Abu Tsaur meriwayatkan dari Imam Syafi'I tentang kebolehan wakaf dinar dan dirham (uang)" ${ }^{15}$

\section{Kajian terhadap Perwakafan Indonesia}

Sudah cukup banyak kajian tentang kegelisahan para akademisi dan masyarakat umum yang "geram" melihat potensi yang begitu besar harta wakaf tetapi belum mampu dikelola secara profesional produktif dan belum secara signifikan berkontribusi terhadap ekonomi umat dan masyarakat luas dalam arti mewujudkan keadilan sosial. Penulis antusias untuk membahas lembaga pendidikan yang telah sukses dari segi pengelolaan dan pengembangan dan ijtihad ekonomi yang melandasinya.

Sebagai awal dari penulisan artikel ini, penulis sudah melakukan penelitian pendahuluan yaitu Muttaqien dan Mu'allim (2013) tentang "Pengelolaan dan Pengembangan Wakaf Tanah di Universitas Islam Indonesia, Yogyakarta”. Penelitian ini menemukan bahwa pengelolaan harta wakaf khususnya wakaf tanah yang dikelola oleh Yayasan BW UII lebih mengarah pada praktek pengembangan harta wakaf produktif. Produktifitas yang dimaksud adalah pengembangan wakaf untuk kegiatan sosial seperti pendidikan dan sarana kesehatan dan pengembangan wakaf yang bernilai ekonomi. Bila dilihat dari segi eksistensi atau wujudnya maka pengelolaan tanah wakaf yang dilakukan oleh Yayasan Badan Wakaf UII adalah Maslahat Mu'tabarah, yaitu, kemashlahatan yang terdapat dalam nas yang secara tegas menjelaskan dan mengakui kebenarannya. ${ }^{16}$

Selain Yayasan Badan Wakaf UII yang dinilai berhasil mengelola wakaf adalah Pondok Modern Darussalam Gontor, Ponorogo, Jawa Timur. Penelitian terhadap lembaga pesantren ini dilakukan oleh Budiharjo (2011), tentang pengelolaan wakaf produktif di Pondok Modern

${ }^{15}$ A. Chairul Hadi, "Peluang Wakaf Produktif untuk Pembiayaan Pendidikan Islam, Jurnal FAI: Turats 5, No. 1, (2009): 16.

${ }^{16}$ Lihat Dadan Muttaqien, Ijtihad dalam Pengelolaan Tanah Wakaf Secara Produktif di Yayasan Badan Wakaf UII (Yogyakarta: DPPM-UII, 2013). 
Darussalam Gontor Ponorogo, penelitian ini menjelaskan bahwa Pondok Modern Darussalam Gontor telah lama mengelola harta benda wakafnya secara produktif jauh sebelum Undang-undang Nomor 41 Tahun 2004, dengan membuka unit-unit usaha di atas tanah wakaf, maupun dengan menggarapnya langsung sebagai lahan perkebunan. ${ }^{17}$ Sedangkan penelitian tentang wakaf di Yayasan Hasyim Asy'ari Pondok Pesantren Tebuireng sejauh penelusuran peneliti hanya ada penelitian Solikah (2012) tentang Tukar Guling Wakaf di Pondok Tebuireng. Penelitian ini sama sekali tidak membahas pengelolaan dan pengembangan dan ijtihad ekonomi. ${ }^{18}$ Demikian juga penelitian Huda, (2011), Pengelolaan Wakaf dalam Perspektif Fundraising: Studi Tentang Penggalangan Wakaf pada Yayasan Hasyim Asy'ari Ponpes Tebuireng Jombang, Yayasan Badan Wakaf Universitas Islam Indonesia Yogyakarta, dan Yayasan Dana Sosial Al-Falah Surabaya. Penelitian ini lebih fokus pada studi penggalangan dana belum menyentuh pengelolaan dan pengembangan secara utuh. ${ }^{19}$

Penulis fokus pada ijtihad ekonomi dalam pengelolaan dan pengembangan harta wakaf pada lembaga pendidikan, selain masalah model pengelolaan dan pengembangan wakaf yang beberapa peneliti telah lakukan secara parsial, oleh sebab itu menjadi penting bagi peneliti untuk meneliti persoalan tersebut secara komprehensif, dengan harapan akan menjadi model dalam berbagai pihak dalam usaha pengelolaan dan pengembangan wakaf.

Untuk mempermudah memahami ruang lingkup dari penulisan artikel ini, penulis menyajikan beberapa teori berkaitan dengaan pengelolaan wakaf serta teori tentang ijtihad ekonomi, bahwa seiring dengan wafatnya Nabi Muhammad Saw., meluasnya wilayah kekuasaan Islam, terpencarnya para sahabat Nabi ke berbagai wilayah, dan banyaknya

${ }^{17}$ Anas Budiharjo, Pengelolaan Wakaf Produktif di Pondok Modern Darussalam Gontor Ponorogo (Yogyakarta: UIN Sunankalijaga, 2011).

${ }^{18}$ Lihat Fitriana Solikah, Tukar Guling Wakaf Pondok Pesantren Tebuireng Jombang (Malang: UIN Maulana Malik Ibrahim, 2012).

${ }_{19}$ Miftahul Huda, "Pengelolaan Wakaf dalam Perspektif Fundraising: Studi Tentang Penggalangan Wakaf pada Yayasan Hasyim Asy'ari Ponpes Tebuireng Jombang, Yayasan Badan Wakaf Universitas Islam Indonesia Yogyakarta, dan Yayasan Dana Sosial Al-Falah Surabaya” (Pascasarjana IAIN Walisongo, 2011). 
para sahabat yang gugur dalam pertempuran, maka umat Islam mendapat tantangan baru di bidang hukum, karena kadang kala masalah (hukum) yang sedang dihadapi tidak ada hukumnya di dalam Alquran dan alSunnah, dan dalam rangka menyelesaikan persoalan-persoalan hukum baru yang sedang dihadapi tersebut, para sahabat selalu ber-ijtihad, dan mereka dapat dengan mudah menemukan hukum atas masalah-masalah yang sedang dihadapi oleh umat Islam kala itu karena para sahabat sangat mengenal tekhnik Nabi ber-ijtihad. ${ }^{20}$

Pola ijtihad di Indonesia telah dibahas secara rinci oleh Mu'allim dan Syibly (2012), Ijtihad Ekonomi Islam Modern. Paper yang telah dipresentasikan dalam Anual International Conference on Islamic Economic 2012, dan dapat dijumpai juga dalam Mu'allim (2012) Hukum Islam dan Ijtihad Keindonesiaan ${ }^{21}$, karya ini menerangkan bagaimana pola-pola ijtihad ekonomi yang dilakukan oleh Ormas Islam, yaitu Muhammadiyah, NU dan MUI. ${ }^{22}$ Dua karya ini akan menjadi salah satu rujukan utama dalam membahas model ijtihad dalam penulisan artikel ini.

Kaitanya dengan kesejahateraan sosial, teori kesejahteraan secara umum dapat diklasifikasi menjadi tiga macam, yaitu classical utilitarian, neoclassical welfare theory dan new contractarian approach. Pendekatan classical utillatarial menekankan bahwa kesenangan (pleasur) atau kepuasan (utility) seseoarang dapat diukur dan bertambah.

Pandangan di atas dapat disimpulkan bahwa tingkat kesejahteraan seseorang dapat terkait dengan tingkat kepuasan (utility) dan kesenangan (pleasure) yang dapat diraih dalam kehidupannya guna mencapai tingkat kesejahteraannya yang diinginkan. Maka dibutuhkan suatu perilaku yang dapat memaksimalkan tingkat kepuasan sesuai dengan sumber daya yang tersedia.

${ }^{20}$ Abdul Wahaf Khallaf, Sejarah Pembentukan dan Perkembangan Hukum Islam (Jakarta: Rajawali Press, 2003), h. 1.

${ }^{21}$ Amir Mu'allim, Hukum Islam dan Ijtihad Keindonesiaan dalam Pribumisasi Hukum Islam (Yogyakarta: Kaukaba, 2012), h. 235.

${ }^{22}$ Lihat M. Roem Syibly dan Amir Mu'allim, Ijtihad Ekonomi Islam Modern (Surabaya: Procceding AICIS 2012, 2012), h. 1602-1620. 


\section{ljtihad dalam Pengelolaan Wakaf}

Ijtihad pada masa sekarang ini jauh lebih diperlukan dibandingkan dengan masa-masa lampau. Berbagai persoalan kontemporer telah muncul ke permukaan dan menuntut kita menyelesaikannya. Persoalan-persoalan tersebut meliputi berbagai bidang kehidupan, mulai dari ekonomi, sosial, budaya, sampai pada masalah-masalah rekayasa genetika dalam bidang kedokteran. Dalam bidang ekonomi, kita menjumpai beberapa kegiatan atau lembaga yang dahulu tidak ada. ${ }^{23}$

Menurut Qardawi, dalam bidang muamalah, lapangan ijtihad yang menuntut jawaban-jawaban baru ada dua bidang. Pertama, bidang ekonomi atau keuangan, dalam bidang ini muncul sederetan bentukbentuk transaksi yang sifatnya tidak pernah dijumpai pada masa dahulu. Kedua, bidang ilmu pengetahuan atau kedokteran. Dalam bidang ini juga ditemukan berbagai cara kegiatan yang memerlukan kejelasan hukum. ${ }^{24}$

Secara normatif idiologis dan sosiologis perbedaan nomenklatur wakaf tersebut dapat dibenarkan, karena landasan normatif perwakafan secara eksplisit tidak terdapat dalam Alquran atau al-Sunnah dan kondisi masyarakat pada waktu itu menuntut akan adanya hal tersebut. Oleh karena itu, wilayah ijtihad dalam bidang wakaf lebih besar daripada wilayah tawqifi-Nya. Keragaman nomenklatur wakaf terjadi karena tidak ada kata wakaf yang eksplisit dalam Alquran dan Hadis. Artinya, ajaran wakaf ini diletakkan pada wilayah yang bersifat ijtihâd $\hat{\imath}$, bukan táabudî, khususnya yang berkaitan dengan aspek pengelolaan, jenis wakaf, syarat, peruntukan dan lain-lain.

Meskipun demikian, ayat Alquran dan Sunnah yang sedikit itu mampu menjadi pedoman para ahli fikih Islam. Sejak masa Khulafa al-Rasyidun sampai sekarang, dalam membahas dan mengembangkan hukum-hukum wakaf digunakan metode penggalian hukum (ijtihad) mereka. Sebab itu sebagian besar hukum-hukum wakaf dalam Islam ditetapkan sebagai hasil ijtihad, dengan menggunakan metode ijtihad

${ }^{23}$ Fathurrahman Djamil, Filsafat Hukum Islam Cet. II. (Jakarta: Logos Wacana Ilmu, 1992), h. 166.

${ }^{24}$ Yusuf Al-Qardawi, Al-Ijtihad al-Muajir, t.t., h. 126. 
seperti qiyas, maslahah mursalah dan lain-lain. Oleh karenanya, ketika suatu hukum (ajaran) Islam masuk dalam wilayah ijtihâdî, maka hal tersebut menjadi sangat fleksibel, terbuka terhadap penafsiran-penafsiran baru, dinamis, futuristik dan berorientasi pada masa depan. Sehingga dengan demikian, ditinjau dari aspek ajaran saja, wakaf merupakan sebuah potensi yang cukup besar untuk bisa dikembangkan sesuai dengan kebutuhan zaman. Apalagi ajaran wakaf ini termasuk bagian dari muamalah yang memiliki jangkauan yang sangat luas, khususnya dalam pengembangan ekonomi lemah.

Ditinjau dari kekuatan sandaran hukum yang dimiliki, wakaf merupakan ajaran yang bersifrat anjuran (sunnah), namun kekuatan yang dimiliki sesungguhnya begitu besar sebagai tonggak menjalankan roda kesejahteraan masyarakat. Dengan demikian, ajaran wakaf yang masuk dalam wilayah ijtihadi dengan sendirinya menjadi pendukung non manajerial yang bisa dikembangkan pengelolaannya secara optimal. Adapun regulasi perwakafan di Indonesia dilihat dari sudut pandang ilmu hukum, maka hukum wakaf telah menjadi hukum positif Indonesia, sehingga memiliki kekuatan imperatif dalam pelaksanaannya, yaitu meliputi: 1) Undang-Undang No. 5 Tahun 1960 tentang Peraturan Dasar Pokok-Pokok Agraria; 2) Undang-Undang No. 41 Tahun 2004 tantang Wakaf; 3) Peraturan Pemerintah No. 42 Tahun 2006 tentang Pelaksanaan UU No. 41 Tahun 2004; 4) Peraturan pemerintah No. 28 Tahun 1977 tentang Perwakafan Tanah Milik. ${ }^{25}$

Harta benda wakaf wajib dikelola secara profesional oleh Nadzir sehingga dapat berkembang sesuai dengan tujuan, fungsi, dan peruntukannya. Karena itu dalam pengelolaan wakaf hendaknya memperhatikan asas-asas yang mendasarinya, yaitu asas keabadian manfaat, asas pertanggung jawaban, dan asas profesionalisme manajemen. ${ }^{26}$

${ }^{25}$ Firman Muntaqo, "Problematika dan Prospek Wakaf Produktif di Indonesia," Jurnal Al-Ahkam 25, no. 1 (April 2015), h. 90-91.

${ }^{26}$ Zainal Arifin Munir, "Revitalisasi Manajemen Wakaf sebagai Penggerak Ekonomi Masyarakat," Jurnal Syariah dan Hukum 5, no. 2 (Desember 2013), h. 162. 


\section{ljtihad Ekonomi dalam Pengelolaan dan Pengembangan Wakaf di YBW-SA}

Secara umum wakaf dan sedekah merupakan modal awal YBWSA berkhidmat dalam dakwah melalui pendidikan dan pelayanan kesehatan. Dari amanah wakaf itulah YBWSA terus menerus berupaya sungguhsungguh untuk mengembangkan usahanya. Dalam buku risalah GKU telah dirumuskan bagaimana seharusnya mengelola wakaf bahwa pengelolaan wakaf berlandaskan iman dan ilmu, serta jama'ah (shaf) yang baik, karena wakaf mengandung makna jaminan kelestarian perjuangan Islam.

Dalam mengemban amanah yang diberikan, YBWSA menetapkan kebijakan pokok dalam mengelola usaha, yaitu:

1. Kebijakan Dalam Bidang Keuangan. Dengan diberlakukannya sentralisasi keuangan, dimana Pelaksana Kegiatan YBWSA menyusun RAPB yang selanjutnya disahkan oleh YBWSA menjadi APB sebagai pedoman dalam penganggaran program dan kegiatan. Beberapa metode yang digunakan dalam penyusunan RAPB pada setiap pelaksanan kegiatan berbeda-beda, di antaranya UNISSULA (Road Map), Dikdasmen (APBS), RSISA (Balance Score Card/BSC). Pada akhir tahun anggaran, yayasan menyusun laporan keuangan yang diaudit oleh akuntan publik sebagai bentuk pertanggungjawaban.

2. Kebijakan di Bidang Sumber Daya Insani (SDI). Sumber daya Insani (SDI) sebagai kekuatan inti seluruh gerak-langkah kegiatan dan usaha yayasan di berbagai bidang, tersebar di seluruh badan pelaksana dan unit kerja di bawah naungan YBWSA. Terdiri dari karyawan tetap dan tidak tetap merupakan kekayaan tak ternilai yang dimiliki Yayasan. Pengadaan sumber daya Insani berdasarkan kebutuhan dan formasi pegawai di masing-masing pelaksana kegiatan YBWSA dengan sistem pengangkatan oleh Yayasan dan penggajian berdasarkan sistem gaji PNS.

3. Kebijakan Pengembangan Fisik. Semua pembangunan fisik di lingkungan YBWSA dilaksanakan oleh Bidang V Pembangunan YBWSA setelah dinyatakan layak menurut kajian Studi Kelayakan oleh konsultan independen. Sedangkan dalam pelaksanaan pembangunan, ketersediaan sumber dana menjadi keniscayaan yang harus ada. Dari 
seluruh pelaksanaan pembangunan yang dilaksanakan oleh YBWSA, pembiayaan tidak hanya berasal dari internal yayasan akan tetapi juga bekerjasama dengan pihak eksternal terutama Lembaga Keuangan Syariah.

4. Usaha-usaha Pengembangan Wakaf. Sebagaimana Visi YBWSA yaitu membangun generasi khaira ummah, menciptakan generasi yang menguasai imtaq dan iptek yang mampu menjadi solusi dan rahmat bagi alam sekitarnya, maka disusunlah usaha-usaha guna memantapkan arah ke depan yang tepat dan benar dengan menyusun sebuah buku induk diberi nama "Risalah Membangun Generasi Khaira Ummah". Buku ini adalah sebagai buku induk atau sebagai basic principles membangun generasi khaira ummah. Penyusunan buku tersebut merupakan hasil kesepakatan dari organ YBWSA (Pembina, Pengurus dan Pengawas), serta Pimpinan Unissula, Pimpinan Dikdasmen, Pimpinan RSISA.

Strategi-strategi kebijakan yang ditempuh dalam pengelolaan wakaf di YBSA adalah; mempertahan keabadian manfaat harta wakaf, mengembangkan manfaat harta wakaf, transparansi dalam pengelolaan harta wakaf, accountable dalam pengelolaan wakaf, dan ke depan diperlukan jaringan wakaf (waqf networking) ${ }^{27}$

Dalam hal pengembangan, YBWSA mengembangkan pembangunan pendidikan berupa Universitas Islam Sultan Agung yang berdiri 20 Mei 1962. Pada tahun 1966 YBWSA mendirikan SMA Islam Sultan Agung, dan pada 17 Agustus 1971 Rumah Sakit Islam Sultan Agung diresmikan operasionalnya. Memasuki tahun 2010 iniYBWSA mengelola beberapa usaha anara lain (1) Pendidikan Dasar dan Menengah: 2 TK, 5 SD, 3 SMP, 3 SMA; (2) Perguruan Tinggi: UNISSULA yang memiliki 11 fakultas dengan 28 prodi; (3) Pelayanan kesehatan dan pendidikankesehatan diwujudkan dalam pendirian RSISA; (4) Kegiatan sosial denganmendirikan LPDU; (5) Dakwah melalui Radio PTDI-UNISA 205 - AM 106.2; (6) Kegiatan bisnis dan (7) LPU pendirian PT. BAP

${ }^{27}$ Lihat "Manajemen Yayasan Badan Wakaf Sultan Agung," t.t., http://ybw-sa.org/profil-ybwsa/ manajemen.html. Dan hasil wawancara dengan Didik Supadie, Sekretaris YBWSA, Mei 2015. 
Berangkat dari amanah yayasan kepada Rektor, UNISSULA diproyeksikan untuk menuju World Class Islamic University, maka pada tahun 2009 UNISSULA mencanangkan untuk melakukan transformasi menuju World Class Islamic Cyber University sejak pelantikan Rektor periode 2009-2013 yaitu Prof. Dr. Laode Kamaluddin. Sedangkan dalam bidang pengelolaan RS, YBWSA telah melakukan berbagai pengembangan. Beberapa program unggulan pengelolaan wakaf berupa Rumah Sakit Islam Sultan Agung adalah Semarang Eye Center (SEC), LASIK Center sebagai brand terbaru dari SEC, Urologi Center, Klinik Reproduksi Sehat, Klinik Kosmetika Medik, Klinik Alternatif dan Komplementer, Rehabilitasi Medic, dan Islamic Teaching Hospital.

Pengembangan wakaf di YBSA terbagi dalam beberapa bidang, yaitu bidang pendidikan, pelayanan kesehatan, kegiatan sosial, bidang dakwah, dan bidang bisnis, lebih rincinya yakni bidang pendidikan terdiri dari 2 Sekolah Taman Kanak-kanak (TK), 5 Sekolah Dasar, 3 Sekolah Menengah Pertama (SMP), 3 Sekolah Menengah Atas (SMA), dan Universitas Islam Sultan Agung yang terdiri dari 12 fakultas dengan 39 program studi.

\section{Yayasan Badan Wakaf Universitas Islam Indonesia Yogyakarta}

Harta wakaf dari masyarakat yang diterima oleh Yayasan BW UII adalah barang tidak bergerak berupa tanah (dalam mendapatkan wakaf tanah UII bersifat pasif, karena wakaf yang diterima harus sesuai dengan ikrar wakif dan kemampuan UII untuk mengelolanya). Yayasan BW UII telah menerima ribuan meter persegi tanah wakaf dari masyarakat, tepatnya sampai tahun 2011 Yayayan BW UII telah menerima 13,561 $\mathrm{M}^{2}$ tanah wakaf di 9 lokasi.

Sampai tahun 2013 ini Yayasan BW UII telah menerima tanaf wakaf di 9 lokasi dari 8 orang wakif dengan luas total 13,561 $\mathrm{M}^{2}$. Sesuai dengan arti wakaf itu sendiri yaitu perbuatan hukum wakif untuk memisahkan dan/atau menyerahkan sebagian harta benda miliknya untuk dimanfaatkan selamanya atau jangka waktu tertentu sesuai dengan kepentingannya guna keperluan ibadah dan/atau kesejahteraan umum menurut syariah. ${ }^{28}$

${ }^{28}$ Lihat "UU No. 41 Tahun 2004". 
Pengelolaan harta wakaf di Universitas Islam Indonesia dilakukan oleh lembaga tertinggi dalam struktur organisasi di lingkungan Universitas Islam Indonesia, yaitu Yayasan Badan Wakaf Universitas Islam Indonesia, yang disingkat dengan YBW UII. Untuk mengelola harta wakaf Yayasan Badan Wakaf membentuk bagian tersendiri yaitu Divisi Pemberdayaan Masyarakat.

Pilihan Badan Wakaf sebagai bentuk kelembagaan pengelola wakaf didasarkan pada pertimbangan, bahwa para pendiri UII berkeinginan memaksimalkan sumber pendanaan Islam yang potensial, baik wakaf, zakat, infaq, dan sedekah yang dapat dipergunakan untuk pembangunan umat. Pengelolaan pendidikan publik dengan menggunakan lembaga wakaf juga dimaksudkan untuk mencegah terjadinya klaim kepemilikan dari pihak-pihak tertentu. Selain untuk memproteksi aset umat tersebut, ide penggunaan wakaf sebagai bentuk kelembagaan juga terinspirasi oleh Universitas al-Azhar. ${ }^{29}$

Dalam hal pengelolaan harta kekayaan yang ada di lingkungan Badan Wakaf UII, harta yang sudah diterima dibedakan menjadi dua, yaitu harta yang murni untuk wakaf yang tidak boleh dijual, dihibahkan dan diwariskan, dan harta yang diterima yang akan digunakan untuk operasional Badan Wakaf UII. Untuk itu ditetapkan dengan rencana Anggaran Pendapatan dan Belanja (RABN) Badan Wakaf UII yang mencakup rencana anggaran untuk kegiatan pengurus harian Badan Wakaf UII, Universitas, Fakultas dan Unit-unit lain yang berada di lingkungan Badan Wakaf UII. ${ }^{30}$

Untuk pengembangan wakaf yang sudah ada, YBWUII juga melakukan penggalangan dana dengan mendirikan unit usaha diantaranya adalah SPBU, PT. UMF-Rumah Sakit JIH, Rumah Sakit JIH, PT. UNISIA Polifarma, PT. Radio UNISI, Hotel UNISI, PT. Jogja Global Utama, PT. UMNU, BPR Syariah, UII Press di bidang percetakan dan penerbitan. ${ }^{31}$

${ }^{29}$ Chaider Bamualim dan Irfan Abubakar, Revitalisasi Filantropi Islam (Jakarta: Pusat Bahasa dan Budaya [PBB] UIN Jakarta, t.t.), h. 256-257.

${ }^{30}$ Wawancara dengan Subowo, Ketua Bidang Pemberdayaan Masyarakat, YBWUII.

${ }^{31}$ Lihat lebih detail tentang hasil usaha dan rencana pengembangan di Yayasan Badan 
Hingga kini YBWUII memiliki 40 ha tanah, baik yang diberikan oleh waqif, maupun dari hasil pembelian. Tanah tersebut tersebar di lima titik di Yogyakarta. Sedangkan sebagian besar tanah wakaf (30 ha) berlokasi di Km. 14 jalan Kaliurang sebagiannya telah dimanfaatkan untuk pembangunan Kampus terpadu.

Hasil wakaf lain berupa keuntungan finansial dari unit-unit bisnis yang didirikan YBWUII. Sebagian keuntungan dipakai untuk membiayai kebutuhan perkantoran yang berkaitan dengan pengelolaan wakaf. Program pengembangan akademik juga memanfaatkan dana hasil wakaf. Pemanfaatan lain adalah untuk peningkatan SDM dosen pada studi lanjut program S2 dan S3 di dalam maupun luar negeri. Di samping itu, hasil wakaf digunakan juga untuk membiayai operasional kegiatan sosial keagamaan dan HAM. Di samping itu hasil wakaf diwujudkan pemberian beasiswa bagi mahasiswa UII yang berprestasi dan mahasiswa tidak mampu. ${ }^{32}$

Dalam pengembangan bisnisnya, Yayasan Badan Wakaf UII membuat arah pengembangan sebagai berikut:

Gambar: Arah Pengembangan Pilar Bisnis Yayasan Badan Wakaf UII

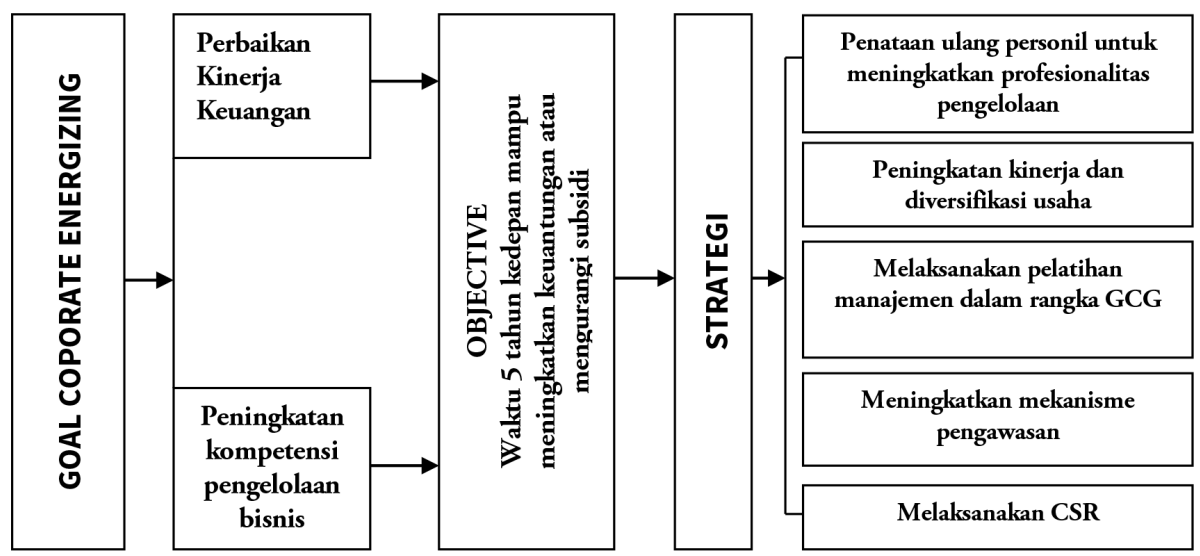

Sumber: Rencana dan realisasi Pengurus YBW UII, Desember 2011.

\footnotetext{
Wakaf UII pada Laporan Tahunan dan Pengembangan, serta rencana dan realisasi kegiatan, yang di sampaikan setiap tahun.

${ }^{32}$ Chaider Bamualim dan Irfan Abubakar, Revitalisasi Filantropi Islam, h. 256-257.
} 


\section{Penutup}

Pengelolaan dan pengembangan wakaf di YBSA dan YBW UII memiliki konsep yang berbeda baik filosofis maupun teknis pengembangan dan pengelolaanya, kesamaan dari keduanya ada pada model kelembagaannya, yaitu dalam bentuk yayasan. YBSA tidak memisahkan harta benda wakaf dengan harta pengembangan wakaf, keduanya merupakan wakaf yang menjadi amanat umat yang harus dikelola secara tanggungjawab dan dikembangkan demi kemajuan peradaban Islam. Wakaf tanah yang pertama YBSA adalah untuk kepentingan Pendidikan Dasar dan kini telah berkembang sampai jenjang Perguruan Tinggi. Tanah Wakaf untuk Pendidikan Dasar dipahami sebagai modal, sedangkan pengembangan hingga perguruan tinggi dan berdirinya rumah sakit merupakan pengembangan wakaf pertama. Sedangkan di YBW UII memisahkan antara harta benda wakaf dan aset pengembangan, keduanya kelola oleh bidang yang terpisah. Sebagian harta merupakan wakaf dan sebagian yang lain bukan wakaf. Harta yang bersumber dari wakaf diperuntukkan untuk kesejahteraan umat. Harta lain yang bersumber bukan wakaf bukan merupakan pengembangan wakaf.

Kedua model pengelolaan dan pengembangan wakaf di atas merupakan ijtihad ekonomi yang mampu menjadikan harta wakaf lebih berdaya guna bagi umat dan kemajuan pendidikan di Indonesia. Yayasan Badan Wakaf mampu mengelola dunia pendidikan secara mandiri bermodal harta wakaf.

\section{Persembahan}

Kami mengucapkan terimakasih yang sebesar-besarnya kepada Kemenristek Dikti yang telah memberikan pendanaan dan dukungan pada penelitian ini, dan terimakasih kami ucapkan juga kepada DPPM UII yang telah memberikan bimbingan sampai selesainya penelitian.

\section{Pustaka Acuan}

“Aset Wakaf Property MUI Singapura Senilai Rp 7,5 T,” t.t., http:// www.beritawakaf.com.

Affandi, Ahmad, and Diah Nurhayati Nufus. "Analysis On Cash Waqf Return Fund Allocation In Indonesia: Acase Study In Indonesian 
Waqf Deposit." In Seventh International Conference-The Tawhidi Epistemology: Zakat and Waqf Economy, pp. 119-135. 2010.

Bamualim, Chaider dan Irfan Abubakar. Revitalisasi Filantropi Islam (Jakarta: Pusat Bahasa dan Budaya [PBB] UIN Jakarta, t.t.), 256-257.

Bukhari, Muhammad Ibn al-. Shahih al-Bukhari, dalam Kitab al-Syurut fi al Waqfi. Bayrut: Dar al-Fikri, 1981.

Budiharjo, Anas. Pengelolaan Wakaf Produktif di Pondok Modern Darussalam Gontor Ponorogo. Yogyakarta: UIN Sunan Kalijaga, 2011.

"Data Direktorat Pemberdayaan Wakaf Kementerian Agama RI," Maret 2016.

Djamil, Fathurrahman. Filsafat Hukum Islam. Cet. II. Jakarta: Logos Wacana Ilmu, 1992.

Djalaludin, Ahmad. "Legitimasi Fiqih Bagi Obtimalisasi dan Pendayagunaan Wakaf”. Iqtishoduna: Jurnal Ekonomi dan Bisnis Islam 3, no. 1, (2007).

Fauzan, Abdullah bin Shalih al-. Minhah Al-Allam fi Syarh Bulugh AlMarram. Cet. ketiga. Dar Ibnul Jauzi, 2011.

Hidayati, Tri Wahyu. Problematika Pengelolaan Wakaf di Indonesia, t.t. Huda, Miftahul. "Pengelolaan Wakaf dalam Perspektif Fundraising: Studi Tentang Penggalangan Wakaf pada Yayasan Hasyim Asy'ari Ponpes Tebuireng Jombang, Yayasan Badan Wakaf Universitas Islam Indonesia Yogyakarta, dan Yayasan Dana Sosial Al-Falah Surabaya”. Pascasarjana IAIN Walisongo, 2011.

Hadi, A. Chairul. "Peluang Wakaf Produktif untuk Pembiayaan Pendidikan Islam. Jurnal FAI: Turats 5, no. 1, (2009).

Hassan, M. Kabir. "An Integrated Poverty Alleviation Model Combining Zakat, Awqaf and Micro-Finance." In Seventh International Conference-The Tawhidic Epistemology: Zakat and Waqf Economy, Bangi, Malaysia, pp. 261-281. 2010.

Htay, Sheila $\mathrm{Nu} \mathrm{Nu}$, Syed Ahmed Salman, Soe Myint, and Haji Ilyas. "Integrating Zakat, Waqf and Sadaqah: Myint Myat Phu Zin Clinic Model in Myanmar." Tazkia Islamic Finance and Business Review 8, no. 2 (2014). 
Syibly, M. Roem dan Amir Mu'allim, Ijtihad Ekonomi Islam Modern. Surabaya: Procceding AICIS 2012.

Zakaria, Azliza Azra Mohd, Rose Ruziana Abd Samad, and Zurina Shafii.

"Venture Philanthropy Waqf Model: A Conceptual Study." Jurnal Pengurusan (UKM Journal of Management) 38. (2013).

Zarka, Muhammad Anas. "Leveraging Philanthropy: Monetary Waqf For Microfinance." In Sharia Compliant Microfinance, pp. 90-94. Routledge, 2013.

Ibrahim, Dahlia, and Hasnidar Ibrahim. "The Revitalization of Islamic Trust Institution Through Corporate Waqf." In 4th International Conference on Business and Economic Research Proceedings. 2013.

Isfandiar, Ali Amin. "Tinjauan Fiqh Muamalat dan Hukum Nasional tentang Wakaf di Indonesia," Jurnal Ekonomi Islam II, no. 1 (t.t.): 55. Ihsan, Hidayatul, and Shahul Hameed Hj. Mohamed Ibrahim. "WAQF Accounting And Management In Indonesian WAQF Institutions: The Cases Of Two WAQF Foundations." Humanomics 27, no. 4 (2011): 252-269.

Jahar, Asep Saepudin. "The Clash Of Muslims And The State: Waqf And Zakat In Post Independence Indonesia." Studia Islamika 13, no. 3 (2006).

Khairuddin, A. R., H. Sharina Farihah, A. S. Azila, O. Jamilah, and A. Srazali. "Preliminary Discussion on the Potential of Zakat-Waqf Collaboration in the Provision of Housing for The Needy Muslims." In Proceedings of the National Conference on Zakat and Economic Development. 2015.

Kholis, Nur. Wakaf dan Upaya Pemberdayaan Potensinya Secara Produktif di Indonesia, dalam Pribumisasi Hukum Islam. Yogyakarta: PPs-FIAI UII, 2012.

Khallaf, Abdul Wahaf. Sejarah Pembentukan dan Perkembangan Hukum Islam. Jakarta: Rajawali Press, 2003.

Mu'allim, Amir. Hukum Islam dan Ijtihad Keindonesiaan dalam Pribumisasi Hukum Islam. Yogyakarta: Kaukaba, 2012.

Muttaqien, Dadan. Ijtihad dalam Pengelolaan Tanah Wakaf Secara Produktif 
di Yayasan Badan Wakaf UII. Yogyakarta: DPPM-UII, 2013.

Muntaqo, Firman "Problematika dan Prospek Wakaf Produktif di Indonesia," Jurnal Al-Ahkam 25, No. 1 (April 2015): 90-91.

Munir, Zainal Arifin. "Revitalisasi Manajemen Wakaf sebagai Penggerak Ekonomi Masyarakat," Jurnal Syari'ah dan Hukum 5, no. 2 (Desember 2013): 162.

“Manajemen Yayasan Badan Wakaf Sultan Agung," t.t., http://ybw-sa. org/profil-ybwsa/manajemen.html.

Nafis, H.M. Cholil. "Reaktualisasi Ajaran Wakaf," t.t., http://bwi.or.id/ index.php/en/publikasi/artikel/637-reaktualisasi-ajaran-wakaf.html.

Nagaoka, Shinsuke. "Resuscitation of the Antique Economic System or Novel Sustainable System?: Revitalization of the Traditional Islamic Economic Institutions (Waqf and Zakat) in the Postmodern Era (Special Feature: Socio-Economic Role of Islamic Finance and its Potential in the PostCapitalist Era).” イスラーム世界研究 7 (2014): 3-19.

Qardawi, Yusuf Al-. Al-ijtihad al-Muajir, t.t..

Raimi, Lukman, Ashok Patel, and Ismail Adelopo. "Corporate Social Responsibility, Waqf System and Zakat System As Faith-Based Model For Poverty Reduction." World Journal of Entrepreneurship, Management and Sustainable Development 10, no. 3 (2014): 228-242. Rahim Abdul Rahman, Abdul. "Islamic Microfinance: An Ethical Alternative To Poverty Alleviation." Humanomics 26, no. 4 (2010): 284-295.

Shirazi, Nasim Shah. "Integrating Zakât And Waqf Into The Poverty Reduction Strategy Of The IDB Member Countries.” (2014).

Solikah, Fitriana. Tukar Guling Wakaf Pondok Pesantren Tebuireng Jombang. Malang: UIN Maulana Malik Ibrahim, 2012.

Undang-Undang No. 41 Tahun 2004

\section{Wawancara}

Didik Supadie, Sekretaris YBWSA, Mei 2015.

Subowo, Ketua Bidang Pemberdayaan Masyarakat, YBWUII. 